\title{
Tobacco Xenobiotics Release Nitric Oxide
}

\author{
Lam EWN, ${ }^{1}$ Kelley EE, ${ }^{2}$ Martin SM, ${ }^{2}$ Buettner GR ${ }^{2}$ \\ ${ }^{I}$ Department of Dentistry, Faculty of Medicine and Dentistry, University of Alberta, Edmonton, Canada \\ ${ }^{2}$ Free Radical \& Radiation Biology Graduate Program and Electron Spin Resonance Facility, \\ The University of Iowa College of Medicine, Iowa City, Iowa, USA
}

\begin{abstract}
Many xenobiotic compounds exert their actions through the release of free radicals and related oxidants [1,2], bringing about unwanted biological effects [3]. Indeed, oxidative events may play a significant role in tobacco toxicity from cigarette smoke. Here, we demonstrate the direct in vitro release of the free radical nitric oxide ( $\mathrm{NO})$ from extracts and components of smokeless tobacco, including nicotine, nitrosonornicotine (NNN) and 4(methyl-N-nitrosamino)-1-(3-pyridyl)-1-butanone (NNK) in phosphate buffered saline and human saliva using electron spin resonance and chemiluminescence detection. Our findings suggest that tobacco xenobiotics represent as yet unrecognized sources of ${ }^{\circ} \mathrm{NO}$ in the body.
\end{abstract}

\section{INTRODUCTION}

Whether generated intracellularly, or exogenously delivered, the diatomic free radical nitric oxide ( $\left.{ }^{\circ} \mathrm{NO}\right)$ is rapidly disseminated throughout the body, affecting key biological processes. Supra-physiologic ${ }^{\circ} \mathrm{NO}$ concentrations favor the formation of a potent biological oxidant; peroxynitrite $\left(\mathrm{ONOO}^{-}\right)$, the reaction product of ${ }^{\circ} \mathrm{NO}$ and the oxygen-centered free radical, superoxide, $\mathrm{O}_{2}{ }^{-}$[4]. Numerous cytotoxic lesions have been attributed to $\mathrm{ONOO}^{-}$, including lipid peroxidation, protein thiol oxidation, inhibition of $\mathrm{Fe}-\mathrm{S}$ enzyme systems, and oxidative DNA lesions such as strand breaks and base modifications, to name some [4-6].

Of the over 30 carcinogens found in tobacco, the nitrosamine compounds, nitrosonornicotine $(\mathrm{NNN})$ and 4-(methylnitrosamino)-1-(3-pyridyl)-1-butanone (NNK) are thought to be the major contributors to the carcinogenic activity of nicotine and tobacco $[7,8]$. NNN and NNK are formed during the curing, aging, and fermentation of tobacco, as well as during nicotine metabolism. Already, $\mathrm{NO}$ generation has been demonstrated in cigarette smoke [9]. The structural similarities between NNN and NNK, and other known therapeutic and experimental ${ }^{\circ}$ NO-releasing compounds suggest that these nitrosamines may be novel ${ }^{\circ} \mathrm{NO}$-releasing agents in tobacco $[10,11]$. Indeed, NNK has been shown to generate DNA strand breaks, as well as induce the formation of DNA adducts, including methylated DNA $[12,13]$.

Here, we demonstrate, using both direct and indirect methods, the in vitro release of ${ }^{\circ} \mathrm{NO}$ from extracts and components of smokeless tobacco, including nicotine, and the nitrosamine metabolites of tobacco, nitrosonornicotine (NNN) and 4-(methyl-N-nitrosamino)-1-(3pyridyl)-1-butanone (NNK).

\section{MATERIALS AND METHODS}

\section{Tobacco xenobiotic preparations}

Experiments were conducted in phosphate-buffered saline (PBS) at $\mathrm{pH} 7.4$ or unstimulated human saliva obtained from healthy, non-users of tobacco, without clinical evidence of periodontal disease. We estimated the mass of a "pinch" of smokeless tobacco to be approximately $2.2 \mathrm{~g}$, and suspended this (Copenhagen ${ }^{\circledR}$ brand, National Tobacco Co., Ltd., Pointe Claire, QB) in $4.4 \mathrm{~mL}$ of PBS or saliva. The

Correspondence: Ermest W.N. Lam, Faculty of Medicine and Dentistry, University of Alberta,

DPC 2085, Edmonton, AB T6G 2N8, Canada

Email: ernest.lam@ualberta.ca

Fax: 780-492-1624 
Table 1. Chemiluminescent detection of ${ }^{\circ} \mathrm{NO}$

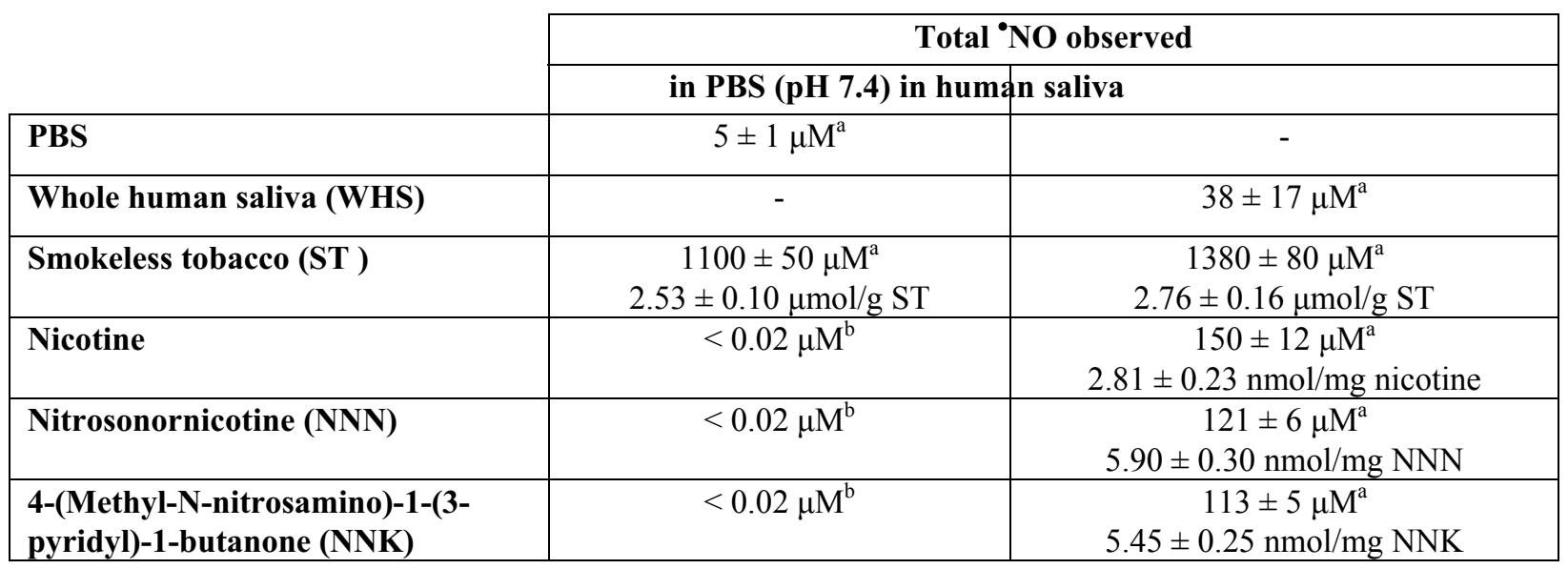

${ }^{\mathrm{a}}$ This is the apparent concentration of ${ }^{\circ} \mathrm{NO}$ present as $\mathrm{NO}_{2}^{-}$in the aqueous incubation injected into the Sievers NOA analyzer.

${ }^{\mathrm{b}}$ The limit of detection with our experimental conditions.

amount of nicotine in this preparation has been determined previously to be $12 \pm 0.7 \mathrm{mg}$ per g tobacco [8]. Therefore, $26.4 \mathrm{mg}$ of nicotine (Sigma Chemical Co., St Louis, MO) was used for the assays. Ten mg of NNN and NNK (Midwest Research Institute, St. Louis, MO) was used for ${ }^{\circ} \mathrm{NO}$ determinations. Each of these prepared solutions was purged with argon gas, and incubated at $37^{\circ} \mathrm{C}$ for $20 \mathrm{~min}$ in an air-tight container before being assayed for ${ }^{\circ} \mathrm{NO}$.

\section{EPR spin trapping}

Each xenobiotic preparation was incubated with a $10 \mathrm{mM}$ solution of the iron (II)/N-methyl-D-glucamine dithiocarbamate, $\mathrm{Fe}^{2+}(\mathrm{MGD})_{2}$, spin trap at $37^{\circ} \mathrm{C}$ for 20 min so that the final concentration of the spin trap was $1 \mathrm{mM}$ [14]. Each $500 \mu \mathrm{L}$ solution was then quickly transferred to an argon-purged flat cell, and EPR spectra were collected with a Bruker (Billerica, MA, USA) $\mathrm{X}$-band EMX spectrometer operating at $9.75 \mathrm{GHz}$, receiver gain of $2 \times 10^{4}$, modulation amplitude of $1 \mathrm{G}$, sweep time of $83 \mathrm{~s}$, and a field center of $3418 \mathrm{G}$ for $\mathrm{NO}-\mathrm{Fe}^{2+}(\mathrm{MGD})_{2}$. Each spectrum represents the signalaveraged sum of 15 acquisitions.

\section{Chemiluminescent detection}

Fifty $\mu \mathrm{L}$ of each xenobiotic solution was injected into a Sievers 280 Nitric Oxide Analyzer (Boulder, CO, USA) containing a reducing agent, KI, potassium iodide $(5.9 \mathrm{mM})$ in glacial acetic acid [14]. Standardization was accomplished by injecting various concentra- tions of a standard solution of $\mathrm{NaNO}_{2}$ into the same reducing environment. Samples were run in triplicate.

\section{RESULTS AND DISCUSSION}

Electron paramagnetic resonance (EPR) spin trapping was used to identify ${ }^{\circ} \mathrm{NO}$ release from tobacco xenobiotics. The EPR-silent ${ }^{\circ} \mathrm{NO}$ spin trap iron (II)/Nmethyl-D-glucamine dithiocarbamate, $\mathrm{Fe}^{2+}(\mathrm{MGD})_{2}$, coordinates the free $\mathrm{NO}$ radical in aqueous solution, forming a stable, EPR-visible spin adduct, 'NO$\mathrm{Fe}^{2+}(\mathrm{MGD})_{2}$. This species yields a characteristic threeline EPR spectrum with an inter-peak hyperfine splitting value, $a_{N}$, of $12.4 \mathrm{G}$ and an isotropic nuclear $g$ value, $\mathrm{g}_{\text {iso }}$, of 2.04, both of which are characteristic of trapped ${ }^{\circ} \mathrm{NO}$ [14] (Figure 1). We observed unstimulated -NO release from smokeless tobacco extract and NNN, and weak release from NNK in PBS. Free ${ }^{\circ} \mathrm{NO}$ was not detected from pure nicotine under these conditions. However, given its chemical structure, we would not expect to observe an EPR signal from nicotine. When these experiments were performed in human saliva under identical conditions, we observed substantially stronger EPR signals. We believe this increased signal strength to be derived, in part, from the reduction of salivary $\mathrm{NO}_{2}^{-}$by cytochrome $\mathrm{cd}_{1}$ nitrite reductase found in some salivary bacteria $[15,16]$. Under these conditions, we observed a substantial EPR signal from nicotine in human saliva. The intensity of this signal suggests there to be substantial biotransformation of 
Figure 1. EPR spectra of the ${ }^{\circ} \mathrm{NO}-\mathrm{Fe}(\mathrm{MGD})_{2}$ spin adduct formed from the release of ${ }^{\circ} \mathrm{NO}$ from tobacco xenobiotics in phosphate buffered-saline at $\mathrm{pH} 7.4$ (left column) and human saliva (right column). The hyperfine splitting value, $\mathrm{a}_{\mathrm{N}}$, of these spectra is $12.4 \mathrm{G}$ and the isotropic nuclear $\mathrm{g}$ value, $\mathrm{g}_{\text {iso, }}$ is 2.04 . (a) $500 \mu \mathrm{L}$ phosphate buffered saline (left column) or whole human saliva (right column); (b) $500 \mu \mathrm{L}$ of a $1: 1 \mathrm{w} / \mathrm{v}$ extract of smokeless tobacco; (c) 3.48 $\mathrm{M}(26.7 \mu \mathrm{G})$ nicotine; (d) $1.1 \mathrm{M}(10 \mathrm{mg})$ nitrosonornicotine $(\mathrm{NNN})$; and (e) $1.0 \mathrm{M}(10 \mathrm{mg})$ 4-(methyl-Nnitrosamino)-1-(3-pyridyl)-1-butanone (NNK). Each spectrum represents 15 summed signal acquisitions acquired using a receiver gain of $2 \times 10^{4}$ and modulation amplitude of $1 \mathrm{G}$. The ordinate scale is $\pm 1 \times 10^{3}$ arbitrary units for all spectra in whole human saliva.

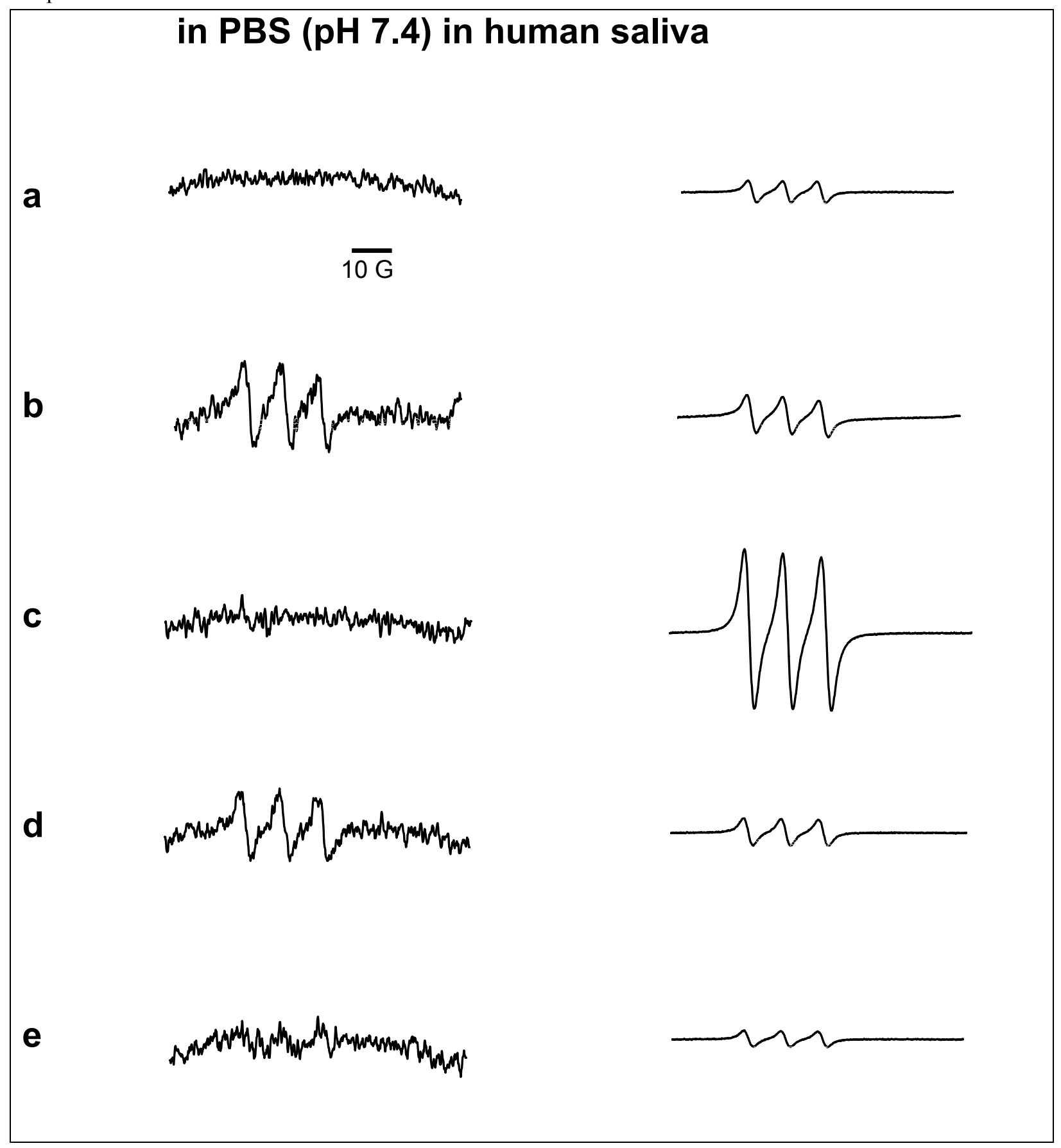


nicotine, facilitating the release of ${ }^{\circ} \mathrm{NO}$. These results suggest that nicotine-derived ${ }^{\circ} \mathrm{NO}$ may substantially contribute to the systemic ${ }^{\circ} \mathrm{NO}$ load to an extent not previously recognized.

As EPR is only semi-quantifiable, we used a chemiluminescence technique to determine ${ }^{\circ} \mathrm{NO}$ concentrations derived from smokeless tobacco xenobiotics. This technique, however, detects only the endproduct of ${ }^{\circ} \mathrm{NO}$ oxidation, namely $\mathrm{NO}_{2}^{-}$. The use of this technique together with EPR spin trapping is considered complementary [14]. The results of these experiments are summarized in Table 1. Briefly, phosphate buffered saline and human saliva generate $5 \pm 1 \mu \mathrm{M}$ and $38 \pm 17 \mu \mathrm{M}{ }^{\circ} \mathrm{NO}$, respectively, while extracts of smokeless tobacco in these fluids produced $1100 \pm 50$ $\mu \mathrm{M}^{\circ} \mathrm{NO}\left(2.53 \pm 0.10 \mathrm{mmol}{ }^{\circ} \mathrm{NO} / \mathrm{g} \mathrm{ST}\right)$ and $1380 \pm 80$ $\mu \mathrm{M}\left(2.76 \pm 0.16 \mathrm{mmol}{ }^{\circ} \mathrm{NO} / \mathrm{g} \mathrm{ST}\right)$, respectively. The similarity of these results may reflect the high inherent $\mathrm{NO}_{2}{ }^{-}$content of processed smokeless tobacco [5]. We were unable to detect ${ }^{\circ} \mathrm{NO}$ from nicotine, $\mathrm{NNN}$ and NNK in PBS; the concentrations of NNN- and NNKderived ${ }^{\circ} \mathrm{NO}$ were likely below the detection threshold of the technique $(0.2 \mu \mathrm{M})$. When nicotine, $\mathrm{NNN}$ and NNK were incubated in human saliva, we detected micromolar (or nanomole quantities per milligram xenobiotic) of ${ }^{\circ} \mathrm{NO}: 150 \mu \mathrm{M} \pm 12$ from nicotine $(2.81 \pm 0.23$ $\mathrm{nmol} / \mathrm{mg}$ nicotine), $121 \pm 6 \mu \mathrm{M}$ from NNN $(5.90 \pm 0.30$ $\mathrm{nmol} / \mathrm{mg} \mathrm{NNN})$ and $113 \pm 5 \mu \mathrm{M}$ from NNK (5.45 \pm $0.25 \mathrm{nmol} / \mathrm{mg} \mathrm{NNK}$ ), respectively. As nicotine and the nitrosamine metabolites are found in milligram and microgram quantities per gram of smokeless tobacco, the putative ${ }^{\circ} \mathrm{NO}$ load derived from these compounds is substantial. Moreover, the importance of saliva in ${ }^{\circ} \mathrm{NO}$ release from these compounds is notable.

Although others have reported free radical, and in particular, $\mathrm{O}_{2}{ }^{-2}$ production in cells exposed to smokeless tobacco and nicotine [17-19], none identified free radical release directly from smokeless tobacco xenobiotics. Tobacco xenobiotics represent as yet unrecognized sources of $\mathrm{NO}$ in the body. Indeed tobaccoderived $\mathrm{NO}$ may have widespread biological implications for tobacco users. Our results also lead us to speculate that ${ }^{\circ} \mathrm{NO}$ and nitrosative events may play a role in tobacco toxicity in the oral cavity and aerodigestive tract.

Acknowledgements: This work was supported by grants from the Canadian Institutes of Health Research and the Alberta Heritage Foundation for Medical Research to E.W.N.L., and the National Cancer Institute to G.R.B.

\section{REFERENCES}

1. Aust SD, Chignell CF, Bray TM, Kalyanaraman B, Mason RP. Free radicals in toxicology. Toxicol Appl Pharmacol 1993; 120:168-178.

2. Kulkarni AP. Role of biotransformation in conceptal toxicity of drugs and other chemicals. Curr Pharm Des 2001; 7:833-857.

3. Eiserich JP, Patel RP, O’Donnell VB. Pathophysiology of nitric oxide and related species: free radical reactions and modification of biomolecules. Mol Aspects Med 1998; 19:221-357.

4. Beckman JS, Koppenol WH. Nitric oxide, superoxide, and peroxynitrite: the good, the bad, and ugly. Am J Physiol 1996; 271:C1424-1437.

5. Quijano C, Alvarez B, Gatti RM, Augusto O, Radi R. Pathways of peroxynitrite oxidation of thiol groups. Biochem J 1997; 322:167-73.

6. Burney S, Caulfield JL, Niles JC, Wishnok JS, Tannenbaum SR. The chemistry of DNA damage from nitric oxide and peroxynitrite. Mutat Res 1999; 424:37-49.

7. Hecht SS, Rivenson A, Braley J, DiBello J, Adams JD, Hoffmann D. Induction of oral cavity tumors in F344 rats by tobacco-specific nitrosamines and snuff. Cancer Res 1986; 46:4162-4166.

8. Hoffmann D, Djordjevic MV. Chemical composition and carcinogenicity of smokeless tobacco. Adv Dent Res 1997; 11:322-329.

9. Tokimoto T, Shinagawa K. Nitric oxide generation in aqueous solutions of cigarette smoke and approaches its origin. Biol Chem 2001; 1613-1619.

10. Feelisch M, Ostrowski J, Noack E. On the mechanism of NO release from sydnonimines. J Cardiovasc Pharmacol 1989; 14:S13-22.

11. Malo-Ranta U, Yla-Herttuala S, Metsa-Ketela T, Jaakkola O, Moilanen E, Vuorinen P, Nikkari T. Nitric oxide donor GEA 3162 inhibits endothelial cell-mediated oxidation of low density lipoprotein. FEBS Letts. 1994; 337:179-83.

12. Liu Y, Sundqvist K, Belinksy SA, Castonguay A, Tjälve H, Grafström RC. Metabolism and macromolecular interaction of the tobacco-specific carcinogen 4-(methylnitrosamino)-1-(3-pyridyl)-1butanone in cultured explants and epithelial cells of human buccal mucosa. Carcinogenesis 1993; 14: 2383-2388.

13. Jorquera R, Castonguay A, Schuller HM. DNA single-strand breaks and toxicity induced by 4 (methyl-nitrosamino)-1-(3-pyridyl)-1-butanone or 
N-nitrosodimethylamine in hamster and rat liver. Carcinogenesis 1994; 15:389-394.

14. Venkataraman S, Martin SM, Schafer FQ, Buettner GR. Detailed methods for the quantification of nitric oxide in aqueous solutions using either an oxygen monitor or EPR. Free Radic Biol Med 2000; 29: 580-585.

15. Duncan C, Dougall H, Johnston P, Green S, Brogan R, Leifert C, Smith L, Golden M, Benjamin N. Chemical generation of nitric oxide in the mouth from the enterosalivary circulation of dietary nitrate. Nature Med 1995; 1:1546-1551.

16. Calmels S, Ohshima H, Henry Y, Bartsch H. Characterization of bacterial cytochrome cd1-nitrite reductase as one enzyme responsible for the catalysis of nitrosation of secondary amines. Carcinogenesis
1996; 17:533-536.

17. Bagchi M, Balmoori J, Bagchi D, Stohs SJ, Chakrabarti J, Das DK. Role of reactive oxygen species in the development of cytotoxicity with various forms of chewing tobacco and pan masala. Toxicology 2002; 179:247-255.

18. Wetscher GJ, Bagchi D, Perdikis G, Bagchi M, Redmond EJ, Hinder PR, Glaser K, Hinder RA. In vitro free radical production in rat esophageal mucosa induced by nicotine. Dig Dis Sci 1995; 40:853-858.

19. Bagchi M, Balmoori J, Bagchi D, Ray SD, Kuszynski C, Stohs SJ. Smokeless tobacco, oxidative stress, apoptosis, and antioxidants in human oral keratinocytes. Free Radic Biol Med 1999; 26:992-1000. 